\title{
Uma história concisa do Holocausto na literatura brasileira
}

A Concise Holocaust Story in Brazilian Literature

\author{
Berta Waldman* \\ Universidade de São Paulo (USP) | São Paulo, Brasil \\ bwaldman@usp.br
}

Resumo: O Holocausto é hoje um tema privilegiado na pauta de discussão de disciplinas distintas das Ciências Humanas e das artes, em outras partes do mundo e também no Brasil. Disseminado em estudos inseridos na rubrica "testemunho na literatura", esse tema e seus desdobramentos compõem um campo interdisciplinar de pesquisas realizadas em diferentes contextos em fase de ampliação e aprofundamento. Trata-se de um work in progress na medida em que o campo de estudos está se delineando e a bibliografia específica ainda é relativamente escassa.

Palavras-chave: Holocausto. Testemunho. Literatura Brasileira.

Abstract: The Holocaust is today a privileged theme in the discussion agenda of different disciplines of the Humanities and arts, in other parts of the world and also in Brazil. Disseminated in studies inserted in the rubric "testimony in literature", this theme and its consequences make up an interdisciplinary field of research carried out in different contexts in the phase of expansion and deepening. It is a work in progress as the field of study is delineating and the specific bibliography is still relatively scarce.

Keywords: Holocaust. Testimony. Brazilian Literature.

My mother was a braid of black smoke.

She bore me swaddled over the burning cities. The sky was a vast and windy place for a child to play.

We met many others who were just like us.

They were trying to put on their overcoats with arms made of smoke. The high heavens were full of little shrunken deaf ears instead of stars.

(Charles Simic)

\footnotetext{
* Doutora em Literatura Comparada e Teoria Literária pela Universidade de São Paulo e Professora Titular da Universidade de São Paulo e Professora Colaboradora da Universidade de Campinas.
} 


\section{Arquivo Maaravi}

O Holocausto marca presença em livros, revistas acadêmicas e simpósios, tendo inclusive transposto essas fronteiras chegando aos jornais, nos idos de 1999, por ocasião dos debates em torno do livro Fragmentos, de Binjamin Wilkomirski, cujo autor fraudou sua identidade ao se apresentar como sobrevivente de um campo de concentração, tendo sido depois de algum tempo desmistificado. ${ }^{1}$ Mas a polêmica, incrementada também por meio de fotografias e filmes sobre o Holocausto, levantou uma questão ética que continua sendo debatida: quem tem legitimidade para narrar as atrocidades cometidas pelos nazistas?

No Brasil, foram escritos textos sobre o Holocausto, principalmente por sobreviventes e imigrantes judeus. Sabe-se também que, durante a Segunda Guerra Mundial, mesmo os judeus distanciados geograficamente da catástrofe, foram atingidos ao sofrerem perdas de familiares e amigos. Os escritores resguardaram-se, em geral, de escrever suas memórias ou de tratar ficcionalmente da Shoah, ${ }^{2}$ esperando o tempo necessário para trabalhar e acomodar as lembranças de uma experiência vivida fora do Brasil e também para ajustar sua sensibilidade ao novo território em que passaram a viver.

Sabe-se ainda que os sobreviventes, após tantos anos da experiência vivida, tiveram que se valer da memória para elaborar seus textos. É preciso frisar, no entanto, que a memória não se opõe ao esquecimento. Ela funciona no meio fio da supressão e da conservação do vivido. Por isso diz-se que ela é seletiva, isto é, ela apreende alguns dados, quando outros passam despercebidos. Além disso, ela é descontínua, lacunar, e sua organização é sempre um artefato de que o memorialista lança mão, preservando ou não os vazios e hiatos que pontuam sua descontinuidade. O livro de Primo Levi É isto um homem?, ${ }^{3}$ por exemplo, mimetiza esse modo de operar da memória ao apresentar-se de forma fragmentária, mantendo, assim, os vazios e os silêncios, entre as partes, oferecendo ao leitor uma descontinuidade metonímica, que potencializa, no entanto, o aflorar de uma figura única: a metáfora do horror.

Esse tipo de narrativa baseada na experiência luta para transformar a memória do passado numa possibilidade do "esquecimento", no sentido de aliviar as angústias e, assim, criar o solo ou a promessa de um futuro. São narrativas catárticas que enfocam a dor, o sofrimento, as injustiças cometidas a pessoas inocentes.

${ }^{1}$ Cf. SELIGMANN-SILVA, Márcio. A literatura do trauma, “Wilkomirski: Os fragmentos de uma farsa". Cult, n. 23, p. 40-47, jun. 1999.

2 Shoah, do hebraico, significa "catástrofe", para designar o assassinato em massa perpetrado durante a Segunda Guerra Mundial. Muitos preferem essa designação a Holocausto, devido ao sentido de imolação, sacrifício, expiação que o segundo termo carrega.

${ }^{3}$ LEVI, Primo. É isto um homem? Trad. Luigi del Re. Rio de Janeiro: Rocco, 1988. 


\section{Arquivo Maaravi}

Elas implicam sempre um pacto entre aquele que conta ou escreve e aquele que ouve ou lê. Esse pacto enfatiza o conteúdo de verdade do que está sendo transmitido e a esse relato chamamos de "literatura de testemunho", gênero que abarca, num primeiro plano, memórias, depoimentos, autobiografia, onde alguém, no presente, remete à experiência passada. O relato pode também organizar-se em forma de diário, cartas, gêneros que se compõem a partir de uma relativa sincronia dos tempos, isto é, relata-se quase ao mesmo tempo em que se vive a experiência. De qualquer modo, o testemunho exige que aquele que relata tenha vivido a experiência contada, restringindo-se à matéria crua de uma vivência concreta, e é isso que daria suporte ao conteúdo de verdade do texto. A condição do testemunho é o compromisso com a verdade, embora não lhe sejam cobradas provas materiais para que se firme esse compromisso.

Uma referência obrigatória, quando se menciona a reflexão sobre a memória, é Maurice Halbwachs, autor de várias obras, entre as quais se destacam os livros Les cadres sociaux de la mémoire (1925) ${ }^{4}$ e A memória coletiva (publicado postumamente em 1950). ${ }^{5}$ Travando um diálogo com as abordagens da psicologia e filosofia de sua época, o autor se contrapôs à ideia de que a memória residiria no interior do indivíduo, como a lembrança de um fato que um dia existiu e pode ser recuperada idêntica ao que foi no momento de seu registro. Ele sugere que a memória seria um processo externo, social. Tratar-se-ia sempre de uma reconstrução do passado, feita a partir dos quadros sociais que estão disponíveis no conjunto mais amplo da sociedade. Nossas lembranças seriam enquadradas na linguagem e seriam sempre construídas dentro de grupos sociais concretos, dependente do relacionamento com a família, classe social, escola. A memória individual seria, assim, um ponto de vista da memória coletiva, e lembrar não implicaria recuperar uma lembrança, mas reconstruí-la a partir de quem se é hoje. ${ }^{6}$

Já Annette Wieviorka inicia L'Ère du témoin com uma frase atribuída ao historiador Simon Doubnov, assassinado por ocasião da eliminação do gueto de Riga, em 1941. Suas últimas palavras teriam sido uma conclamação para que os companheiros "não

\footnotetext{
${ }^{4}$ HALBWACHS, Maurice. Los marcos sociales de la memória. Trad. Manuel A. Baeza e Michel Mujica. Barcelona: Anthropos Editorial; Concepción: Universidad de la Concepción; Caracas: Universidad Central de Venezuela, 2004.

${ }^{5}$ HALBWACHS, Maurice. A memória coletiva. Trad. Laurent León Schaffter. Rio de Janeiro: Vértice Editora/Revista dos Tribunais, 1990.

${ }^{6}$ Cf. LERNER, Kátia. Memórias da dor: coleções e narrativas sobre o Holocausto. Brasília: MinC/IBRAM, 2013. p. 21.
} 


\section{Arquivo Maaravi}

Revista Digital de Estudos Judaicos da UFMG

ISSN: $1982-3053$

se esquecessem" e "contassem", "escrevessem" sobre as brutalidades sofridas nas mãos de seus opressores. ${ }^{7}$

Desse modo, a questão da lembrança e do esquecimento tem sido recorrente na literatura sobre o Holocausto. Primo Levi, por exemplo, afirmou em Os afogados e os sobreviventes ${ }^{8}$ que os que sobreviveram teriam "ficado para testemunhar". Algo semelhante foi afirmado por Elie Wiesel, quando, ao relatar sua experiência na guerra em seu livro $A$ noite, ${ }^{9}$ repetiu numerosas vezes "Nunca me esquecerei". A memória, portanto, não passou despercebida na produção acadêmica brasileira sobre o tema. ${ }^{10}$

Já o campo de forças que articula a memória e a literatura de testemunho resume-se à necessidade de narrar e à insuficiência da linguagem em recobrir o real, pondo de manifesto a cisão entre linguagem e evento, criando-se, assim, a polarização paradoxal entre necessidade e impossibilidade, pesando sobre a segunda os limites expressivos da linguagem, como também a categoria excessiva e inverossímil de realidade a ser transmitida. ${ }^{11}$

São muitos os sobreviventes que expressaram a incredulidade dos ouvintes em relação às primeiras notícias dos campos de extermínio nazistas. ${ }^{12} \mathrm{~A}$ noção de absurdo foi instrumentalizada pelos perpetradores do genocídio, que queriam apagar os rastros de seus atos, sabendo que poderiam contar com a incredulidade do público. É o próprio Lévi que cita em Os afogados e os sobreviventes um episódio contado por Simon Wiesenthal que reproduz a fala de um nazista: “Seja qual for o fim desta guerra, a guerra contra vocês nós ganhamos; não restará ninguém para dar testemunho, mas mesmo que alguém escape, o mundo não lhe dará crédito."

\footnotetext{
${ }^{7}$ WIEVIORKA, Annette. L'Ère du témoin. France: Plon, 1998.

${ }^{8}$ LEVI, Primo. Os afogados e os sobreviventes. Trad. Luiz Henriques. Rio de Janeiro: Paz e Terra, 1990.

${ }^{9}$ Cf. WIESEL, Eli. A noite. Trad. Irene Ernenst Dias. Rio de Janeiro: Ediouro, 2006.

10 Cf. SELIGMANN-SILVA, Márcio. A história como trauma. Pulsional: Revista de Psicanálise, n. 116/117, 1998/1999; SELIGMANN-SILVA, Márcio; NESTROVSKI, Arthur (Org.). Catástrofe e representação. São Paulo: Escuta, 2000; SELIGMANN-SILVA, Márcio (Org.). História, memória, literatura. O testemunho na era das catástrofes. Campinas: Editora da Unicamp, 2003; e JEHA, Julio NASCIMETO, Lyslei (Org.). Estudos Judaicos: Shoá, o mal e o crime. São Paulo: Humanitas, 2012.

${ }^{11}$ A propósito, vale lembrar a passagem da Poética de Aristóteles, em que o autor afirma: "Deve-se preferir o que é impossível, mas verossímil, ao que é possível, mas não persuasivo." E, ainda, de Boileau (século XVIII): “O espírito não se emociona com o que ele não acredita." (Arte Poética, III, 5a).

12 LEVI, 1990.
} 


\section{Arquivo Maaravi}

O peso maior em relação à impossibilidade de narrar recai sobre o trauma vivido, que funciona como um bumerangue que retorna sempre a seu lugar de origem. Sabe-se por intermédio de Freud que a experiência traumática é aquela que não pode ser totalmente assimilada enquanto ocorre, resistindo, assim, à simbolização. ${ }^{13}$ Nesse caso, o testemunho seria a narração não tanto dos fatos violentos vividos, mas da resistência à compreensão dos mesmos. Por mais que a linguagem tente cercar e estabelecer limites àquilo que não foi submetido a uma forma, ela fracassa, e ao derrapar promove a repetição da cena traumática. ${ }^{14}$

Há quem argumente que é a história e não o relato da experiência vivida que é capaz de levar a um grau de compreensão do acontecido durante a Segunda Guerra Mundial. ${ }^{15} \mathrm{O}$ que está em questão em relação ao ocorrido em Auschwitz, diriam os defensores da história, não é a morte individual, que pode ser contada pela memória, mas o genocídio de um povo executado por um Estado moderno no coração da Europa em pleno século XX. Ao historiador, aos pesquisadores, cientistas sociais, caberia recuperar as memórias, os fragmentos individuais e demais rastros e torná-los compreensíveis. A eles caberia superar a barreira do intangível para entender a organização do Estado alemão a partir de 1933, para articular a gramática interna da ideologia, sua potência, sua atuação em esferas da vida social e psicológica, a emergência dessa ideologia na história da Alemanha e da Europa e como ela se apossou do Estado e como este organizou, pela primeira vez na história, um plano sistemático de destruição de todo um povo. ${ }^{16}$

Por outro lado, há também aqueles que argumentam que se a vivência da barbárie do século XX coube a alguns milhões de seres humanos, a experiência do extermínio é de todos nós. Só a literatura, ou a arte, poderia desafiar a intraduzibilidade do Holocausto, transmitindo-o de maneira mais cabal.

Como conjugar os dois apelos inconciliáveis - a necessidade de contar e sua impossibilidade - a não ser na palavra literária? Da palavra que significa pelo que diz e pelo que cala, capaz de estimular um encontro mais efetivo com o vivido, e, por

${ }^{13}$ Cf. SELIGMANN-SILVA, Márcio. O testemunho: entre a ficção e o "real". In: História, Memória, Literatura. O testemunho na Era das Catástrofes. Campinas: Editora da Unicamp, 2003. p. 59-90.

${ }^{14}$ Cf. SELIGMANN-SILVA, Márcio. Reflexões sobre a Memória, a História e o Esquecimento. In: SELIGMANN-SILVA, 2003, p. 375-390.

${ }^{15}$ Cf. CYTRYNOWICZ, Roney. O silêncio do sobrevivente: diálogo e rupturas entre memória e história do Holocausto". In: SELIGMANN-SILVA, 2003, p. 125-140.

${ }^{16}$ Cf. BAUMAN, Zygmunt. Modernidade e ambivalência. Trad. Marcus Penchel. Rio de Janeiro: Jorge Zahar, 1999. 


\section{Arquivo Maaravi}

seu intermédio, frear os sentidos estratificados e estabelecidos de uma experiência de abismo tateável, porém intangível?

No domínio estritamente estético, o abalo da razão e da linguagem tem consequências drásticas para a produção artística. Criar em arte e também no pensamento de modo geral após Auschwitz significa não só rememorar os mortos, mas também acolher, no próprio movimento de rememoração, a presença do sofrimento. A inclusão do sentimento na linguagem demanda a palavra literária. A escolha do tom, da forma, do andamento narrativo, são traços inerentes à criação. A capacidade de aludir sem dizer, de fazer emergir metáforas sem explicitá-las, tudo isso é trabalho artístico que alcança mais do que qualquer tipo de linguagem chegar perto da "verdade" do ser e da vida.

Criar uma obra de arte e não um relato, não implica omitir os fatos relativos a uma época e aos acontecimentos que se desenvolveram nela. Primeiro, porque a ficção relacionada à Shoah lida com fatos históricos e não imaginários. Segundo, porque a arte representativa também ela aspira a desvelar-nos a "verdade" do mundo. Quando a história serve de ponto de partida à ficção, são permitidas ao escritor algumas liberdades em relação ao desenvolvimento exato dos fatos, mas elas servem de alavanca para chegar a um ponto escondido, submerso, de difícil acesso. É a possibilidade de construir esse atalho que atribui superioridade à poesia sobre a história, como já afirmavam os antigos.

Claude Lanzmann, diretor do célebre filme Shoah, pensa nessa mesma direção quando afirma: “O filme pode ser algo mais que um documento, pode ser uma obra de arte, e pode ser igualmente verídico."17

Também o filósofo Emanuel Lévinas, após sua leitura do polêmico Iossl Rákover dirige-se a Deus, de Zvi Kolitz, ${ }^{18}$ releva o texto ficcional em detrimento do documento: "Acabo de ler um texto belo e verdadeiro, verdadeiro como só a ficção pode ser." É claro que são necessários todos os cuidados para não transformar a lembrança do horror em mais um produto cultural a ser consumido. Para que isso não ocorra, a estilização artística não pode tornar Auschwitz digerível, transformando a experiência traumática em mercadoria de sucesso. A dimensão ética da matéria precisa ser preservada acima de tudo, exigência obedecida de diferentes maneiras pelos escritores que trataram do Holocausto.

17 TZETAN, Todorov. Em face do extremo. Trad. Egon de Oliveira Rangel e Enid Abreu Dobránsky. Campinas: Papirus, 1995. p. 278.

${ }^{18}$ ZVI, Kolitz. Iossl Rákover dirige-se a Deus. Trad. Fábio Landa. São Paulo: Perspectiva, 2002. p. 79. 


\section{Arquivo Maaravi}

No âmbito da literatura brasileira, um apanhado relativamente completo até agora do que se escreveu sobre a Shoah está elencado no livro de Regina Igel, Imigrantes judeus/escritores brasileiros. ${ }^{19} \mathrm{O}$ propósito deste artigo não é apresentar o conjunto dos textos publicados sobre o assunto, mas trazer para a reflexão alguns exemplos de como a literatura brasileira configurou as atrocidades perpetradas durante a Segunda Guerra Mundial, de que modo diferentes gerações, em diferentes tempos, no Brasil, a representaram. ${ }^{20}$

\section{Jacó Guinsburg}

O escritor nasceu na Bessarábia e aportou no Brasil com sua família aos três anos de idade, pouco depois da Revolução de 1924. Editor, ensaísta, tradutor, professor de teatro e de literatura, Guinsburg foi o primeiro, no Brasil, a publicar ficção sobre a Shoah. Seu conto "O retrato", escrito em 1946, foi publicado em 1949.21

A narrativa enfoca a guerra vista a partir do Brasil, provavelmente São Paulo, num relato que se faz em primeira pessoa, por meio de um narrador-personagem jovem, filho de pais emigrados da Romênia

O conto focaliza a família composta por um filho, pai e mãe, divididos entre o seu lugar de origem, país em guerra, e o Brasil, sua nova terra. A notícia da guerra chega ao país principalmente pelo jornal. Neste, estão as manchetes bombásticas e altissonantes, que contracenam com um modo restrito, silencioso e individual de comunicação - a carta, esperada pela família desde o início do conto, sendo o presumido emissor um tio que vivia com a família na Bessarábia. A carta seria o aval de sua sobrevivência.

Em âmbito familiar, a Europa distante fixa-se simbolicamente no retrato de um primo jovem conterrâneo. Esse retrato ocupa lugar estratégico na sala de estar da casa, funcionando como ponto de confluência de olhares, pensamentos, e também como marcação de uma ausência, de uma falta.

Os dois planos tensionados - fora e dentro, distante e próximo, ausência e presença vão interagir durante a narrativa. Fora, a guerra, que chega por intermédio da notícia de jornal, que corre em meio a um mundo estranho a ela, soando na mesma toada que a música no rádio do vizinho, no mesmo cenário que ocupa a prostituta na esquina recostada num poste à espera de um freguês. Aqui (no Brasil), em meio a uma indiferença geral, o conto releva a ansiedade de uma família judaica à espera de notícias sobre a sorte dos entes queridos.

\footnotetext{
${ }^{19}$ IGEL, Regina. Imigrantes judeus/escritores brasileiros, São Paulo: Perspectiva, 1997.

${ }^{20}$ A ordem da apresentação é cronológica, refere-se, pois, à data das publicações.

${ }^{21}$ GUINSBURG, Jacó. O retrato. O reflexo, n. 8, São Paulo, 1949.
} 


\section{Arquivo Maaravi}

O narrador, um jovem adaptado ao país, quer desvincular-se do destino dos judeus, ainda que sejam seus familiares. O retrato do primo mais jovem é, na sua visão, um objeto entre outros da casa, notação que vai se alterando ao longo do relato. Sua rotina é a de todo jovem de sua geração. Inclui a visita às prostitutas da zona do meretrício, a cervejinha nos bares, e o sonho de ampliação de seu horizonte de ação, viajando, quem sabe, para os EUA.

Enquanto isso, as notícias de jornal anunciam: "Ultimato de Hitler! O bárbaro crime! Olha a Folha! Olha o Diário!", "Hitler invadiu a Polônia! Começou a guerra!" e "Assinada a paz! A paz!".

Em quatro páginas, o conto marca o transcurso de duração da guerra, tempo suficiente para o jovem narrador ir se deslocando de sua posição de indiferença com relação à sua origem e passar a identificar-se com ela por intermédio do pai, vindo a sofrer com ele os desastres de um mundo que, ao final, tinha sido desmantelado, sobrando dele apenas o retrato na moldura, e o silêncio de uma carta que não chega.

\section{Samuel Rawet}

Imigrante polonês, Rawet nasceu na pequena aldeia de Klimotow, em 1931, e aos sete anos desloca-se, com a mãe e os irmãos, para seguir o pai, que já havia emigrado para o Brasil uns anos antes. Instalam-se na periferia do Rio de Janeiro e a marca do descentramento sela sua obra como um todo. O conto "O Profeta" insere-se no livro Contos do imigrante, que data de 1956.22

Nesse texto, um narrador em terceira pessoa dirige a cena literária, ao mesmo tempo que o protagonista permanece em silêncio. Como que prosseguindo o conto " $\mathrm{O}$ retrato", mas mudando seu desfecho, toma parte dessa cena um sobrevivente sem nome dos campos de extermínio, recém-chegado ao país, para encontrar seus parentes já fixados no Brasil há cerca de trinta anos. Estes o ridicularizam numa língua ininteligível para ele, acuando-o ao silêncio e apartando-o do convívio familiar, organizado em torno de um novo eixo. $\mathrm{O}$ aburguesamento da família sinalizado no conto pelo deslizar do automóvel último tipo, do apartamento luxuoso, se faz acompanhar de novos hábitos, como o jogo de cartas, risadas tolas e fuxicos. A felicidade e o conforto conquistados não condizem com uma disposição humanitária de ouvir a história que o velho tinha a contar - para que se fixar na tristeza?, dizem eles. Essa recusa coloca o velho num lugar de estranhamento do qual ele não sairá. Com seu capote preto e as barbas brancas, passa a ser chamado pejorativamente entre os familiares de "profeta". Também na sinagoga ele é ridicularizado e chamado do mesmo modo. Os profetas na Bíblia tinham por função conduzir o povo por um caminho determinado por Deus, sua voz precisava ser

${ }^{22}$ RAWET, Samuel. Contos do imigrante. Rio de Janeiro: José Olympio, 1956. 
ouvida. No conto, a palavra do profeta está em baixa. O alheamento familiar prevalece e ninguém ouve o sobrevivente, porque ouvi-lo implicaria quebrar a carapaça da alienação. Ao final, o velho arruma sua mala e parte sem ter para onde ir, marcando o não-lugar como sendo o que resta aos que sobreviveram ao Holocausto. Neste ponto, vale lembrar que vários sobreviventes especificam em seus relatos a dificuldade em contar a barbárie a que tinham sido submetidos, porque não lhes davam crédito, porque suas histórias entristeciam os ouvintes que as recusavam.

Marcando sua solidariedade com aquele que sofre, o narrador recorta a frase permeando-a de pausas, para criar no plano estilístico uma homologia com aquilo que é contado. Assim, o conto deve ser entendido por meio da palavra e do silêncio, que aqui significa toda uma história que está sendo omitida.

\section{Meir Kucinski}

Em Imigrantes, mascates $\mathcal{E}$ doutores, lançado em 2002, ${ }^{23}$ apresenta narrativas publicadas originalmente em Israel, em 1963. Imigrante proveniente da Europa Oriental, Polônia, Kucinski chegou ao Brasil aos 29 anos, em 1935, e aqui desempenhou papel importante na vida intelectual judaica, tendo se dedicado, entre outras atividades, ao jornalismo e ao ensino do ídiche e de sua literatura, no Colégio Renascença. Sua língua de expressão foi o ídiche, tendo suas narrativas sido traduzidas para o português.

O conto "Mitzves, boas ações" põe em evidência os conflitos entre os judeus já estabelecidos no Brasil e aqueles que vieram na qualidade de sobreviventes da Shoah. As partes em conflito são as mesmas que as apresentadas por Rawet, em "O Profeta". Só que elas não representam parentes consanguíneos, mas pessoas originárias da mesma cidadezinha - Scheradz (Polônia). Os primeiros imigrantes dessa região já haviam organizado sua associação de ajuda mútua em São Paulo e chegara a hora de recepcionar e apoiar uma família (Iossl, sua mulher, Sara e os dois filhos) sobrevivente do Holocausto.

Se o gesto é positivo e informa os modos de organização dos judeus imigrados na nova terra - eles montam uma sapataria para o sustento de Iossl e sua família - aliase a ele um traço de onipotência, já que Iossl não foi consultado se desejaria trabalhar nessa profissão. De certo modo, o bom gesto foi mal direcionado e acabou por gerar efeitos catastróficos, por reduzir o suposto beneficiado a objeto sem direito a opinião. A ação é corrigida no segundo auxílio espontâneo que a família recebe, vindo, dessa

${ }^{23}$ KUCINSKI, Meir. Imigrantes, mascates $\mathcal{E}$ doutores. Coord. Rifka Berezin e Hadassa Cytrynowicz). São Paulo: Perspectiva, 2002. 
vez, de vizinhos judeus da Bessarábia, que atuam segundo um padrão ético de respeito ao outro.

O mesmo núcleo de conflito reaparece no conto "O Tio", do mesmo autor, que contrapõe a família de Moische Wolf, já perfeitamente ajustada ao Brasil, ao recémchegado Iossl, sobrinho do primeiro e sobrevivente do Holocausto. O autor não romantiza nem idealiza as relações familiares. Os que pertencem à mesma linhagem e formam uma família consanguínea são estranhos uns aos outros e não há afeto desinteressado permeando o contato. $\mathrm{O}$ diferente, o que veio de longe e traz uma marca de sofrimento, é evitado. Sua chegada não deve interferir na rotina familiar, ele não deve contar a ninguém sua experiência nos campos, espera-se que apague a expressão de dor desenhada em seu rosto e que atue como os demais que não passaram pelo Holocausto, porque já estavam no Brasil, onde trabalharam duro, mas venceram, isto é, juntaram negócio, casa própria e a possibilidade de proporcionar estudo aos filhos. Quem sabe Iossl poderia vir a ser o genro que buscavam, casando com sua filha única?

Do jovem saía um odor envelhecido de campo de concentração. Os andrajos que vestia como que contavam do trabalho de "desinfecção", dos vapores dos barracões, de alguém que se apresentava para o serviço militar. ${ }^{24}$

Transformá-lo à força em genro, não podiam, mas o jovem não escaparia de ser mascate, refazendo o destino do tio e de tantos outros judeus aqui chegados. $\mathrm{O}$ narrador em terceira pessoa, para acentuar a solidão do sobrevivente, mostra-o perdido na língua portuguesa que desconhece:

Iossl, com as mãos deformadas pelos pesados trabalhos forçados no campo de concentração, com o número tatuado no braço, não entendia claramente nem o que eles chamavam "pegar no batente", nem o que queria dizer "progredir", apesar de o tio falar e resmungar, desde o primeiro minuto essas palavras. ${ }^{25}$

Recusando-se a apagar a violência inerente às relações humanas e, particularmente, negando-se a tratar do judeu como um bloco homogêneo, Kucinski mostra a "família" judaica em estado de conflito, empenhada em ocultar e reprimir uma história indesejada. Cego à sua responsabilidade em relação ao outro, o tio reproduz a lógica assassina instaurada pelo nazismo, reduzindo o sobrinho a um número de matrícula sem rosto, ao mesmo tempo em que desmorona o edifício de princípios éticos que devem reger a conduta de judeus e não-judeus. $O$ conto termina lançando o sobrevivente numa bruma de incompreensão, espaço em que a lei moral está suspensa:

${ }^{24}$ KUCINSKI, 2002, p. 194.

${ }^{25}$ KUCINSKI, 2002, p. 195. 


\section{Arquivo Maaravi}

Iossl, com as pernas bem abertas, a ossuda face em chamas e o olhar vago, olhava sem entender para o pacote, como para um cadáver. Lembrou-se do chicote, no campo de concentração, que silvava como as palavras do tio: "No Brasil, se a gente quer, a gente é um tio, se não quer, não se comporta como um tio..."26

\section{Guimarães Rosa}

Um dos mais importantes ficcionistas da literatura brasileira contemporânea, atuou como vice-cônsul na embaixada brasileira em Hamburgo, Alemanha, durante a Segunda Guerra Mundial. Sabe-se que era conhecedor da língua alemã e leitor de vários autores de sua literatura, como Kafka, Musil, Thomas Mann e Goethe. ${ }^{27} \mathrm{Em}$ Ave, palavra, ${ }^{28}$ há três contos que remetem à Segunda Guerra: "O mau humor de Wotan", "A velha" e "A senhora dos segredos". Neles, o autor se detém com sutileza na preocupação de alguns personagens que interagem com o narrador em torno do que podia ocorrer e estava, de fato, ocorrendo na Alemanha. O narrador trabalha em uma embaixada, enquanto as personagens centrais e femininas em dois dos contos ("A velha" e "A senhora dos segredos") pedem-lhe que as ajude a sair do país em guerra. A situação é próxima àquela apontada pela historiografia, segundo a qual Guimarães Rosa foi, de fato, procurado por judeus que tentavam sair da Alemanha e escapar da morte certa, mediante passaportes que permitiriam a eles aportar no Brasil. $^{29}$

O conto "O mau humor de Wotan" apresenta um casal formado por Hans Helmut Heubel e Márion Madsen inseridos na Alemanha em guerra. O marido é chamado duas vezes a se juntar ao exército alemão. A esposa teme por ele que não tem o perfil de soldado e expõe sua preocupação ao narrador-personagem, amigo do casal. Quando volta da primeira convocação, Hans Helmut expressa numa reunião com conhecidos: "da guerra, vi apenas cavalos e cachorros, mortos, felizmente..." ao que o narrador-personagem observa: "Era um nenhum relato, dito de acurtar conversa." Entretanto, participava da reunião o casal Annelise e o Capitão K, para quem a afirmação soou antipatriótica. Enquanto Hans Helmut ganha um período de desmobilização temporária para auxiliar o pai no reflorestamento de uma grande área de sua propriedade que interessava ao país, os encontros com o narradorpersonagem se repetem e as conversas embalam uma lógica argumentativa desconsolada, porém tranquila. Em um desses encontros, tem-se o seguinte: "Sul-

\footnotetext{
${ }^{26}$ KUCINSKI, 2002, p. 196.

${ }^{27}$ Ver, a propósito: SOETHE, Paulo Astor. A imagem da Alemanha em Guimarães Rosa como retrato auto-irônico. Scripta, Belo Horizonte, v. 9, n. 17, p. 287-301, 2005.

${ }^{28}$ ROSA, Guimarães. Ave, palavra. Rio de Janeiro: Livraria José Olympio Editora, 1970.

${ }^{29}$ TUCCI-CARNEIRO, Maria Luiza. O anti-semitismo na era Vargas. São Paulo: Perspectiva, 2001.
} 
americano, você deseja a vitória dos países conservadores. Mas, nós, alemães, mesmo padecendo o Nazismo, como podemos querer a derrota? Que fazer?"

Embora não torcesse pela derrota, Hans Helmut era pouco afeito à guerra e à política que a motivava. À certa altura, há uma correção de rota: a divisão a que se vinculava o soldado se move para outra parte e sua esposa comunica ao narrador: "desta vez, ele partiu acabrunhado, profundo, sei que sem segurança. E sim... Temo que tenha medo..." 30 Ao leste, "rasgam a Rússia - máquinas de combate rolam através da estepe, como formigas selvagens. Porém diante, um duro defensor morria matando, ou se abriam só ruinas e o caos da destruição, como no segundo versículo: a terra malcriada - despejada e monstruosa - tôhu-vabôhu"31

É estratégico o lugar da citação bíblica, em hebraico, nesse momento do conto. Literalmente tôhu vabôhu se traduz como o substrato amorfo - sem forma e vazio porém maleável - a partir do qual todos os outros elementos da Terra se formam. Em síntese, esse planeta é apresentado como um caos construtivo, gerador de vida. ${ }^{32}$ A expressão citada, portanto, alude, no texto original, à criação. Porém, a expressão tôhu vabôhu é entendida, no conto, como "a terra malcriada - despejada e monstruosa", referida à expansão da guerra ao Leste, em que máquinas de combate rolam pelas estepes, "como formigas selvagens". Assim, o mesmo termo é utilizado com sentidos opostos. O sentido negativo é incorporado à observação do narrador, que recebe do protagonista um cartão do lugar em que se trava a batalha (Rússia) escrito às presas:

E o pior é ter de avançar, dias inteiros, pela planície que nunca termina. Meus olhos já estão cansados. Raramente enxergo um trigal, choupanas. Chove, e a lama é aferrada, árdua. O russo se retrai com tal rapidez, que nunca os vemos. ${ }^{33}$

Com o avanço da guerra ao leste, o desastre é de tal monta que o coração do amante se contrai, "grande como a paisagem sármata e a desolação sagrada da ausência". Aí o texto retoma de forma alusiva a citação de Gênesis, tohu vabohu, para marcar que a desolação sagrada do vazio foi preenchida pelo caos da guerra, atribuindo a ela uma dimensão negativa e descomunal.

Nesse ínterim, Márion tem as cartas do marido devolvidas pelo correio, sinalizando sua morte. Ela reconstrói para o narrador o encontro dela própria e do marido com o pai de Annelise (o Dr. Schwartz), em que este desfiava as façanhas da Wehrmacht, na

\footnotetext{
${ }^{30}$ ROSA, 1970, p. 9.

${ }^{31}$ ROSA, 1970, p. 10.

${ }^{32}$ Veja-se a citação bíblica na Bíblia de Jerusalém, em que o texto é traduzido diretamente do original. São Paulo: 7ª impressão. Sociedade Católica Internacional e Paulus, 1995.

${ }^{33}$ ROSA, 1970, p. 10.
} 
França, na Bélgica, e em resposta Hans Helmut retruca "ora eu, da guerra, só vi uns cachorros e cavalos, mortos, felizmente...". O Dr. Schwartz, depois de poucos dias reconvoca Hans Helmut para a tropa, sob seu comando, e assim, despreparado para o combate, ele foi morto. Em papel tarjado veio a fórmula:

Hans Helmut Heubel passou, e deram-lhe ao corpo a cruz-de-ferro. Seus traços ficarão em chão, ali onde teve de caber no grande fenômeno, para lá do Dniéper, nas estepes de Nogai. Ninguém fale, porém, que ele mais não existe, nem que seja inútil hipótese sua concepção do destino e da vida. Ou que um dia não venham a ser bemaventurados os mansos, porque eles herdarão a terra.

O conto mostra a brutalidade do regime nazista em confronto com uma ética pacifista. Algo como o choque entre Wotan, deus da guerra, versus o homem condenado a sua arbitrária individualidade. Esse desfecho arma também um espaço de confluência possível para se pensar na difícil posição de Guimarães Rosa, diplomata do Brasil durante o Estado Novo, vivendo na Alemanha no auge do nazismo, avalizando, na contramão, uma ética pacifista.

Por mais que o escritor fosse desfavorável à politização da literatura (lembre-se que seu grande modelo da literatura alemã era Goethe), ele estabelece uma relação estreita com a Alemanha entre 1938 e 1942, portanto, entre o auge e a derrocada do estado nazista, período em que atuou como vice-cônsul junto à embaixada brasileira de Hamburgo. É durante esse período que transcorre seu conto "A velha". Nele, enquanto o narrador personagem faz o caminho que o leva à casa da velha, observa não só a intensidade do frio como os elementos que se destacam no percurso:

Via-se, a cada canto, o emblema: pousada num círculo, onde cabia oblíqua a swástika, a águia de abertas asas. [...] O coração daquela natureza era manso, era mau?"34

Também na casa que o narrador personagem visita havia uma:

invernia de austeridade, o cheiro irrenovável mofo e de humanidade macerada. [...] Assustava a esdruxularia daquele ambiente solífugo e antimundano, de sopor e semiviver, o sentido de solidão [...]. Esperava-se encontrar, em torno, duendes e lêmures. Encontravam-se criaturas - ao todo cinco mulheres, todas velhas, que se retraíam, estafermáticas, estornicadas nas vestes de veludo ou gorgorão de lã, de golas altas, longas mangas, terrível decoro. ${ }^{35}$

\footnotetext{
${ }^{34}$ ROSA, 1970, p. 108.

${ }^{35}$ ROSA, 1970, p. 109.
} 


\section{Arquivo Maaravi}

É inevitável o curso do presente da enunciação no ato de narrar o passado, porque ele tem uma hegemonia reconhecida na marcação de uma experiência fenomenológica. Em outras palavras, "o presente dirige o passado como um diretor de orquestra a seus músicos", ${ }^{36}$ enquanto o passado muitas vezes se contorce para dar-lhe coerência. Cinco mulheres idosas esperam empertigadas a visita do embaixador: Dame Verônika, Dame Angélika, sua filha, e três parentas. A mais anciã, quase centenária, colocada no centro, era quem desejava falar-lhe. Em meio a muito constrangimento, Dame Verônika passa a conversar com o cônsul em português. Nesse momento, o relato se desdobra e revela uma espécie de alçapão imprevisível. "Era como se falasse figura, de um álbum desbotado." ${ }^{37}$ Ela conta ter vivido com o marido, judeu, em Petrópolis, em tempos idos, o convívio com o Imperador, que estudava hebraico. Enquanto a fala transcorre, as quatro damas continuam presentes, distantes e hirtas, sem nada entender. Dona Verônica prossegue, dirigindo-se exclusivamente ao interlocutor com uma informação: "A filha não tinha sangue da outra raça - Por que, pois?" 38 Entenda-se a elipse, por que correr o risco do extermínio que o nazismo impôs aos judeus e a outras minorias, se sua filha não era judia? Depois de tantos anos, sem nenhuma testemunha, a história soa para o interlocutor como descabida e ele logo não alimenta as esperanças da velha: "Não, em fato. Não. Tive de sacudir a cabeça. Dame Angelika nem mesmo era brasileira." ${ }^{39}$ Nisso, "num rebrilho de alma" a velha exclama: "Ele foi um vosso compatriota um homem nobre... O amor de minha vida!..." ${ }^{40}$ Essa declaração soa extemporânea: o sistema do mundo, a velha, o passado, o presente são peças que não se articulam mais. E não há como ajudar a velha a mudar a filiação judaica de Frau Angelika e, talvez, o seu destino.

Já o conto "A senhora dos segredos" alude à magia. Inicia mencionando cartomantes, astrólogos, horóscopos e Frau Heelst, a dita horoscopista de Hitler. Um grupo resolve visitá-la em Volksdorf, perto de Hamburgo, para saber o que a vida reservava a cada um. Satisfeitos mais ou menos o grupo foi atendido e o cônsul brasileiro volta quase um ano depois a Volksdorf para fazer à Frau uma pergunta pronta: "Haverá guerra?" A que a senhora responde: "Ach, nee... De modo nenhum. Sossegado esteja." 41

\footnotetext{
${ }^{36}$ Ver: SARLO, Beatriz. Tiempo pasado: cultura de la memoria y giro subjetivo - una discusión. Buenos Aires: Siglo XXI Editores Argentina, 2005. p. 65.

${ }^{37}$ ROSA, 1970, p. 109.

${ }^{38}$ ROSA, 1970, p. 110.

${ }^{39}$ ROSA, 1970, p. 111.

${ }^{40}$ ROSA, 1970, p.111.

${ }^{41}$ ROSA, 1970, p. 212.
} 
Depois de uma discussão de como se chegava a investigar astrologicamente o assunto, a cartomante confirma que não iria haver guerra. Numa manhã, liga de Volksdorf Frau Heelst aflita. Ela pedia ajuda para emigrar para o Brasil, qualquer canto onde pudesse ganhar seu sustento... pedia a documentação, urgia partir... $\mathrm{O}$ conto termina com a fala do narrador: "Não, não era mais possível. Nada deixavam os astros. Doze dias depois começava a guerra." ${ }^{42}$

Ao relatar semelhante episódio, Guimarães Rosa estaria problematizando questões relacionadas ao contexto histórico em que vivia? Certamente, na qualidade de funcionário do consulado brasileiro em período de guerra o escritor deve ter sido muito procurado para auxiliar judeus que procuravam escapar da sanha nazista. A quem prestar e/ou recusar ajuda? Como se davam esses tipos de tramitações? A História pode vir em nosso auxílio. ${ }^{43}$ Mas da estrita leitura dos contos tem-se que, ao ser procurado, o narrador aborta a possibilidade de ajudar os solicitantes a escapar da fúria nazista. Com certeza, a concretização do pedido estava fora de suas possibilidades.

Conforme Jaime Ginzburg,

[...] nos três relatos, o centro de interesse não está no núcleo do poder nazista, nem na descrição dos horrores a que foram submetidos os grupos perseguidos pelo regime. As três personagens femininas estão dentro do contexto alemão, e isso lhes confere uma posição singular no processo histórico: elas são vítimas, impotentes em sua impossibilidade de controlar o andamento da história social. Estão sujeitas às decisões do regime. Trata-se, de fato, como indica João Camillo Penna, de uma imagem da política como multicentralidade: a história não se divide apenas entre alemães e suas vítimas, como querem muitos discursos estereotipados, mas dentre os próprios alemães o regime desperta medo e cria tensão. ${ }^{44}$

Rosa, ciente das atrocidades e ambivalências da Alemanha que tanto admirava, retratadas em dois de seus contos através da omissão do diplomata brasileiro diante de quem lhe implora asilo, não abdica da visão de um futuro positivo para o diálogo e cooperação entre os espaços culturais e sociais brasileiro e alemão.

\footnotetext{
42 ROSA, 1970, p. 213.

${ }^{43}$ Cf. TUCCI-CARNEIRO, 2001.

${ }^{44}$ Cf. GINZBURG, Jaime. Guimarães Rosa e o terror total, In: CORNELSEN, Elcio; BURNS, Tom (Org.). Literatura e guerra. Belo Horizonte: Editora UFMG, 2010. p. 17-27.
} 


\section{Arquivo Maaravi}

Apesar de Rosa ter retratado no nível ficcional a omissão em auxiliar personagens que procuravam fugir da Alemanha nazista, na história real, ocorreu o oposto. Isso porque consta que a esposa do escritor, Aracy Moebius de Carvalho Guimarães Rosa, homenageada no Museu do Holocausto de Washington (EUA) e, em Jerusalém (Israel), no museu Yad Vashem, ajudou muitos judeus a entrarem ilegalmente no Brasil durante o governo de Getúlio Vargas. Isso só poderia ter ocorrido com a discreta aquiescência de seu marido.

\section{Moacyr Scliar}

Em A Guerra no Bom Fim, de Moacyr Scliar, ${ }^{45}$ pode-se notar que no itinerário percorrido pelo protagonista Joel e seus companheiros da infância à idade adulta, o escritor demarca muito bem a representação do judeu já nascido no Brasil, inserindoo num fogo cruzado de culturas figurado literariamente na heterogeneidade de vozes narrativas. No nível do enredo, as colagens de realidades e contextos distintos, são recursos utilizados pelo autor; graças a eles convivem em sua obra diferentes níveis de realidade. Por exemplo, Scliar transporta a Segunda Guerra Mundial a Porto Alegre e os filhos de imigrantes investem fantasiosamente contra os nazistas, na terra e no mar, na praia e nas ruas, ajudados por heróis díspares que vão do Deus Jeová ao Homem Borracha, do Golem ao Príncipe Submarino, de Sansão ao Homem Montanha. Aí, é inegável a aproximação da ficção de Scliar com a vaga hispanoamericana do realismo fantástico, pouco desenvolvido na literatura brasileira. Num movimento oposto, o autor finca os personagens num tempo histórico, fazendo-os viver sua história pessoal presa ao microgrupo familiar, ao macrogrupo do gueto, ambos inscritos no painel da História brasileira, de onde ecoam, no romance, sinais, como a expansão do parque fabril de São Paulo, a morte de Getúlio Vargas, os movimentos estudantis e de esquerda. Uma vez crescidas, o inimigo das crianças não é apenas o nazista, mas o mesmo que assola a classe média brasileira: a pobreza. Se, por um lado, judeus e negros mantêm, além da vizinhança topográfica (a Colônia Africana é ao lado do bairro do Bom Fim), uma equivalência de destinos determinada pela pobreza comum, por outro lado, essa equivalência tenderá a se romper, porque a ascensão social será franqueada aos judeus mas brecada aos negros, que se manterão miseráveis.

Um exemplo privilegiado do cruzamento de culturas que caracteriza a ficção de Scliar pode ser avaliado no modo como o autor traz a barbárie nazista para Porto Alegre. O Brasil havia acolhido uma grande leva de alemães nazistas depois da Segunda Guerra Mundial. Assim, quando os filhos do alemão Ralf Schmidt resolvem prender o velho judeu Samuel para presenteá-lo ao pai no dia de seu aniversário, já estavam criados os suportes de verossimilhança. $\mathrm{O}$ autor, entretanto, terá que

${ }^{45}$ SCLIAR, Moacyr. A guerra no Bom Fim. Rio de Janeiro: Expressão e Cultura, 1972. 


\section{Arquivo Maaravi}

utilizar o fantástico e enquadrar o episódio no Carnaval, momento de inversão da ordem, para levar adiante os aspectos grotescos e mórbidos dos acontecimentos.

Os filhos de Ralf matam gratuitamente o velho judeu e, como não sabiam o que fazer com o corpo, transformam-no em churrasco; nesse momento, eles estão promovendo a passagem de uma expressão metafórica a literal, e alçando a situação ao plano fantástico. É a mulata Maria, mãe das crianças criminosas, que, em sua ignorância (ela não sabe o que o leitor sabe), começa a comer o corpo de Samuel. Para além dos aspectos macabros que o episódio suscita, podemos interpretá-lo pelo viés antropofágico. Quando Maria come a carne humana, o autor a transforma numa canibal nativa. Ela é a autóctone em oposição ao marido e aos filhos (que se parecem ao pai), o europeu civilizado, branco, loiro. Pelo comportamento do branco europeu e do nativo, o leitor é levado a avaliar uma das consequências banais da colonização: a corrupção dos nativos pelo europeu, este o verdadeiro bárbaro, numa inversão clara da óptica colonialista. Com este episódio, Scliar ilustra um crime macabro, ao mesmo tempo que inclui uma tomada de posição com relação ao processo bárbaro de colonização a que o branco e europeu submeteu o Brasil e a América Latina.

\section{Samuel Reibscheid}

Em Memorial de um herege, ${ }^{46}$ romance de Samuel Reibscheid, médico nascido em São Paulo e filho de pais imigrantes, o autor cria uma narrativa que se estrutura a partir do anárquico relato de Guenia Bronia, médium praticante de artes ocultas, transcrito pelo narrador conforme mensagem "psicocomputadorizada" recebida do além. De viés bem brasileiro, esse influxo místico é usado como recurso de criação de verossimilhança, sendo caudatário dos numerosos documentos, cartas, bilhetes, encontrados por acaso e que se desdobraram em tantos romances do século XIX e mesmo do século XX.

Ele é, entretanto, apenas a antessala de um relato escrito aos jorros, onde a ironia e o humor ácido oxidam a letra expandida numa pluralização de narrativas interligadas a partir de um evento vivido pelo protagonista, o médico Isaac Ben Maimon, preso numa cidade do interior de São Paulo e envolvido num processo kafkiano, já que se desconhecem os motivos da acusação. Esse é o dínamo que desencadeia uma torrente de horror. Segundo as homologias criadas no relato, somos levados a pensar que o autor crê haver uma continuidade nos atos de manifestação do autoritarismo através dos tempos. Mudam as vítimas, os poderes, o processo é idêntico. Assim, justapõem-se e misturam-se as ações da Inquisição com os horrores do Holocausto e com os atos de tortura perpetrados pelas ditaduras latino-americanas e outras. A partir desse princípio de equivalência, as partes vão sendo costuradas, juntando-se

${ }^{46}$ REIBSCHEID, Samuel. Memorial de um herege. São Paulo: Ateliê Editorial, 2000. 


\section{Arquivo Maaravi}

peste bubônica e Aids; Hitler e Eichmann que dançam uma valsa antes de serem despejados num esgoto; o rei Davi e Moshé Dayan; Inquisição e os porões da ditadura; gritos de horror escancarado e vozes de crianças brincando, tendo como fundo pregões de vendedores de iguarias. Tudo registrado pelo olho de uma polaroide pós-moderna que não teme o excesso. $\mathrm{O}$ excremento, a mutilação, a morte, orquestrados para relevar a desordem do irracionalismo, não poupam o leitor, lançado também ele num espetáculo do qual se subtrai qualquer moldura de referências de um mundo em progresso.

Memorial de um herege sustenta-se numa história que sistematicamente vitimiza as minorias. O preconceito e a intolerância estão à espreita violentando e liquidando prostitutas, comunistas, anarquistas, pobres, negros, doentes terminais, judeus, homossexuais, o cidadão comum. O tratamento que o autor atribui ao Holocausto equaliza outras vitimizações que afligem o homem moderno e contemporâneo, tirando daquela catástrofe o caráter particular e único que os autores anteriores se esforçam em delinear. É como se fosse da natureza humana subjugar e aniquilar o outro, o diferente, o mais fraco. Assim, o escritor transpõe as guaritas dos campos de concentração de Auschwitz para fincá-las contra o céu azul dos trópicos, mais particularmente do Brasil, denunciando atrocidades enterradas na vala comum do silêncio e do esquecimento.

\section{Roney Cytrynowicz}

A coletânea de contos $A$ vida secreta dos relógios e outras histórias, de Cytrynowicz, ${ }^{47}$ publicada em 1994, marca a presença de uma terceira geração de escritores pósShoah. Um dos eixos de sua ficção é a figura do avô, que nos leva de volta ao Bom Retiro, no bairro da Luz, em São Paulo, bairro de concentração de judeus que veio sendo ocupado por coreanos, grupo pertencente a uma leva imigratória mais recente. É ali que o avô estrangeiro vive e ali o narrador criança o visita, dormindo em sua casa às sextas feiras, embalado por uma língua que lhe é estranha - o ídiche que os mais velhos utilizam. É também ali que o narrador presencia, por intermédio do empenho do avô, um colecionador de relógios, o modo como ele consertava suas batidas, numa simbiose íntima e perfeita com eles. Mas os relógios e seus ritmos são incontroláveis. Mudam de lugar à noite, aparecem e desaparecem, e a sincronia entre todos torna-se uma tarefa inalcançável, sinalizando para tudo aquilo que escapa ao domínio do homem. O conserto dos relógios alude ao conserto do mundo - em hebraico tikun olam - que, segundo a tradição, aponta para a necessidade de retornar à perfeição pela obediência aos preceitos. Metaforicamente diz-se que uma única letra errada compromete a existência do mundo. Mesmo cuidando de apenas quatro

${ }^{47}$ CYTRYNOWICZ, Roney. A vida secreta dos relógios e outras histórias. São Paulo: Página Aberta, 1994. 


\section{Arquivo Maaravi}

letras combinadas em duas palavras - tic tac - a missão do avô não se cumpre, tarefa impossível num mundo marcado pelo absurdo e pelo extermínio. É pela figura do avô e dos de sua geração que o escritor traz à tona as reminiscências dos campos de concentração nazistas nesta e em outras narrativas.

\section{Halina Grynberg}

Mameloshn: memória em carne viva, ${ }^{48}$ de Halina Grynberg, configura o relato de sua vida como uma espécie de texto de formação, pontuado pela Shoah. Pertencente à segunda geração pós-catástrofe, a autora empreende o esforço de desvencilhar-se de uma história marcada pela destruição e pelo trauma vivenciados por ela como herança da história dos pais. Sua mãe, nascida em Varsóvia, escapa do gueto e, após uma fuga mirabolante, encontra refúgio num Campo da Sibéria, onde se torna garçonete no refeitório de oficiais. Enquanto isso, a família materna morre nos campos de concentração. De seu pai pouco se trata. Sabe-se que nasceu numa aldeia da Polônia central, Goworowo, e que aprendeu a profissão de padeiro/confeiteiro com o pai, tendo saído ileso da guerra. O exílio da família passa por Haifa, Marselha, Paris, etapas anteriores à chegada ao Brasil, e a violência a que estavam submetidos internaliza-se, expande, e eles aliam à condição de vítimas a de agressores na relação que alimentam entre si. É a narradora adulta que recusa o fardo dessa herança ambígua, e enxerga a si, criança demandante, insistindo em se aproximar dos pais, mas ao mesmo tempo resistindo em deixar-se anular como sujeito.

"Eu me salvei: por dentro disse não!" O que significa dizer "não"? Para a segunda geração pós-Holocausto, a catástrofe pode não estar no passado, mas no presente, quando os efeitos do trauma original se fazem sentir por intermédio de configurações distintas e distantes do golpe primordial. ${ }^{49}$ Nesse sentido, em cada criança, filha de sobrevivente, existiria um Holocausto particular. O evento histórico já está distante, inalcançável, e não é ele que ganha espaço neste livro. Ao dizer "não!" A narradora recusa o fardo de uma herança e desvencilha-se do pacto de compartilhar o legado de lembrar a catástrofe, ao menos em moldes canônicos, que escamoteiam o efeito do evento em cada um.

O legado da memória, ${ }^{50}$ um dos fundamentos do judaísmo, que deve ser assumido coletiva e individualmente de modo a preservar o passado no presente sob forma reatualizada, encontra na Shoah um lugar privilegiado. Ali, um depósito de lembranças, misto de reminiscências individuais, familiares e coletivas de dizimação

${ }^{48}$ GRYNBERG, Halina. Mameloshn: memória em carne viva. Rio de Janeiro: Record, 2004.

${ }^{49}$ FICHER, Efraim (Ed.). Breaking Crystal: Writing and memory after Auschwitz. Urbana and Chicago: University of Illinois Press, 1998.

${ }^{50}$ Cf. YERUSHALMI, Yossef Hayim. Zakhor: Jewish History and Jewish Memory. Washington: University of Washington Press, 1982. 


\section{Arquivo Maaravi}

e extermínio não podem ser negligenciadas nem esquecidas. Mas, a pergunta que fica é: a obrigação de lembrar deve ser cumprida segundo uma forma, um modelo, ou é possível abrir-se para a multiplicidade de modos de impressão na memória?

A problematização de como carregar esse legado, ou mesmo se carregar o legado, ou ainda para quê e para quem se deve transmitir a memória da Shoah deve ser silenciada? De quem é essa memória? Trata-se de uma memória que metaforiza a desumanidade que recai apenas sobre os judeus ou ela é de propriedade universal? Deve essa memória incluir a dos deficientes físicos e mentais, ciganos, homossexuais, prisioneiros políticos e outras vítimas do nazismo? De quem é essa memória, afinal?

Esse questionamento implícito em Mameloshn está explicitado em alguns textos da literatura israelense como Adam ben Kelev ${ }^{51}$ (1969), de Yoram Kaniuk, Aien erech: ahavá, de David Grossman, ${ }^{52}$ por exemplo, e obrigam o leitor a encarar o problema. $\mathrm{O}$ primeiro descreve Israel como o maior manicômio do mundo, por se tratar de um estado fundado a partir do Holocausto. Altamente irônico e agressivamente cínico, o romance de Kaniuk despreza várias noções convencionais, incluindo as de sanidade e loucura, numa tentativa vigorosa de entender a Shoah. A necessidade de se apartar do trauma dos mais velhos e firmar uma identidade própria está presente também no segundo romance mencionado, em que o Holocausto passa para um registro que rebate muitas das coordenadas do cânone oficial. Grossman e Kaniuk não idealizam as vítimas; suas propostas são as de tornar inteligíveis os efeitos das atrocidades no sobrevivente. A disrupção entre gerações ocorre e não há como vedá-la no tratamento que esses escritores dão ao tema.

No livro de Halina Grynberg, o sujeito que narra constrói um discurso que enlaça a fala do outro, principalmente a da mãe e a do pai, constituindo um discurso direto livre, que indicia, desde o início, planos de continuidade/descontinuidade distintos entre os três. A continuidade impossível e tudo o que ela acarreta forja basicamente a experiência relatada, transformando o narrado numa arena de luta onde o sujeito se procura e se perde, se reencontra, à medida que vai dando forma a seu nome próprio, Guítele, Aline, Halina, em contexto brasileiro.

O nomadismo e a situação de exílio geográfico não impedem que a família carregue consigo a língua materna - o mameloshn - solo dos afetos, da tradição e da cultura. $\mathrm{O}$ ídiche ganha uma contraface depois da Segunda Guerra Mundial, pois passa a registrar em si os escombros e o fantasma da destruição dos judeus da Europa. Ao mesmo tempo em que transmite toda uma história dos judeus da Europa Oriental,

\footnotetext{
${ }^{51}$ KANIUK, Yoram. Adam filho de cão. Trad. Nancy Rozenchan. São Paulo: Globo, 2003.

${ }^{52}$ GROSSMAN, David. Ver: amor. Trad. Nancy Rozenchan. Rio de Janeiro: Nova Fronteira, 1993.
} 
inclusive daqueles que foram dizimados na Shoah, esse idioma chega ao Brasil e desdobra-se no uso que dele se faz, além de atuar como força perturbadora que acena a um pertencimento.

Uma vez no Brasil, em Madureira, subúrbio do Rio de Janeiro, a família vai aderindo a alguns sinais externos que designam outros imigrantes judeus pobres no país: a filha entra para a escola pública e em seguida para o Ginásio Israelita I. L. Peretz; o pai mascateia pelos labirintos do baixo meretrício; a mãe cuida da casa. Marcando esse encontro de mundos contrastantes, a linguagem da narradora mescla impressões enquanto vai-se operando sua inserção no país: “O pó dos cremados bailava na escuridão até pousar sobre mim, Quarta-Feira de Cinzas em mim sempre." As cinzas misturam a morte dos judeus com o sacrifício de Cristo, criando uma sobreposição entre ambos.

No episódio em que a mãe força a filha a comer, temerosa que ela morresse, como tantas crianças nos guetos e campos de concentração, há dois sinais antagônicos transmitidos simultaneamente: o desejo de alimentar (vida) e a tortura na forma de alimentar (morte). Assim também em relação ao uso da mameloshn. "A mão que sufoca é a mesma que dá de comer": eis o bordão que atravessa o relato. Assim,

Mamãe me reclinava de costas sobre seu colo. Com o cotovelo esquerdo forçava minha cabeça para baixo enquanto tapavame as narinas com os dedos livres. Sufocada em terror, o grito retido por detrás dos dentes cerrados, acabaria por entreabrir os lábios para a colher empunhada pela mão direita que empurrava a comida goela abaixo. ${ }^{53}$

É ainda no interior dessa ambiguidade que se pode entender a relação entre pais e filha, todos "parceiros na incoerência". As figuras materna e paterna dominam explicitamente o projeto autobiográfico, pois o livro trata de uma subjetividade que emerge de uma história familiar. Além de importante presença, pai e mãe cumprem a função de marcar uma identidade, uma cultura e a história dos judeus que se transmite por intermédio deles. Mas há uma cesura que se instaura entre a geração dos pais e a da filha, cujo esforço é o de criar um enredo de vida diverso da história de seus pais. Ao final, a filha dá à mãe o lugar de continente de sua escritura e estabelece com ela uma relação de pertinência. É em mameloshn que se nomeiam os capítulos deste livro - cuja imagem inicial traz mãe e filha enoveladas, suplantada na imagem final em que a filha abandona simbolicamente pai e mãe no ventre da noite, ciente de que para perdoar é preciso não esquecer. Quanto à nossa obrigação de lembrar,

${ }^{53}$ GRYNBERG, 2004, p. 69. 
certos textos da literatura de testemunho mais recente não nos deixam esquecer que os mortos podem mudar de lugar dentro de nós.

Por que os atos genocidas praticados por nazistas durante a Segunda Guerra Mundial conseguiam passar camuflados ou pouco evidentes, enquanto ocorriam? Por que os documentos altamente secretos apareciam mascarados sob criptônimos como Umsiedlung (deportações), quando na realidade se tratava de extermínio? $\mathrm{O}$ filósofo Horst Aspernicus ${ }^{54}$ e o filólogo e professor de literatura românica Victor Klemperer ${ }^{55}$ se debruçaram sobre a língua alemã utilizada durante o nazismo e concordam que há nela uma chave dupla em que reside sua ambiguidade. Os alemães queriam ser vistos como arianos nobres, heroicos, triunfantes e, ao mesmo tempo, eram assassinos de seres indefesos. Apregoavam o primeiro, executavam o segundo, e daí vem o extenso catálogo de frases feitas como Arbeit macht frei (O trabalho libera) ou palavras como Umsiedlung ou mesmo Endlösung (solução final) como eufemismos para o crime. Mesmo que os nazistas tenham cometido crimes os mais terríveis, não desejavam revelá-los. Eles não queriam permanecer na história como assassinos. A manipulação da linguagem, neste caso, tem a função de forjar e edulcorar a história e seus acontecimentos. ${ }^{56} \mathrm{~A}$ abundância dos superlativos, o prestígio dos chavões, as pretensões eruditas em linguagem empolada, misteriosa, cheia de preciosismo, esnobismo e pompa, têm a ver com o obscurantismo kitsch do período nazista. A linguagem constrói uma realidade idealizada e camufla o crime, o assassinato, chamados de "expedições punitivas". Neste caso, o eufemismo e os circunlóquios no uso da linguagem funcionam como "elementos encobridores da história".

\title{
9 Cíntia Moscovich
}

\begin{abstract}
${ }^{54}$ LEM, Stanislaw. Provocación. Madrid: Editorial Funambulista, 2005. (Prowokacja, 2003).
${ }^{55}$ KLEMPERER, Victor. LTI: a linguagem do terceiro Reich. Trad. Apresentação e notas de Miriam Bettina P. Oelsner. Rio de Janeiro: Contraponto, 2009.

${ }^{56}$ De acordo com o trabalho de Ciryl Azlanov sobre "O multilinguismo nos campos de concentração" (inédito), Como se sabe, a capacidade básica de comunicação era uma condição imprescindível para sobreviver nos campos de concentração. $\mathrm{O}$ único modo possível de sobrevivência foi a utilização da língua do carrasco. Essa língua era uma variação do alemão falado pelos SS e pelos delinquentes alemães. Não era só um socioleto, como também a fala de uma geração inteira, a geração do Terceiro Reich. Como costuma acontecer em sociedades revolucionárias (e, desse ponto de vista, o regime nazista foi revolucionário apesar de suas caraterísticas ultrarreacionárias), os extratos baixos da sociedade alçaram-se a posições de responsabilidade e de poder, trazendo consigo hábitos linguísticos populares em vez de adotar as normas das elites. A nivelação da língua pela base provocou uma significativa simplificação das estruturas linguísticas, de modo que este alemão empobrecido foi relativamente fácil de aprender para quem ainda não o conhecia.
\end{abstract}




\section{Arquivo Maaravi}

Revista Digital de Estudos Judaicos da UFMG ISSN: $1982-3053$

A escritora, natural de Porto Alegre, introduz o judaísmo como um dos elementos estruturantes de sua obra. A família, o encontro entre gerações e as transformações que se vão instaurando na passagem do tempo criam enredos, oposições, choques, atropelos. Nesse contexto, "ser judeu" é um conceito cambiante e muitos dos conflitos entre pais e filhos estão relacionados a essa transformação. O judeu no Brasil, a imigração, a mudança de hábitos e de idioma, os casamentos mistos, ao mesmo tempo a memória dos antepassados, são sublinhados pela autora com agudeza e humor. Também a passagem pela Shoah e seus efeitos nos judeus de terceira geração atravessam os relatos da escritora. Destaco a seguir cenas construídas a partir de figuras de linguagem que se caracterizam em produzir novos e múltiplos sentidos.

Em "Contar garfadas. Como num campo de concentração," 57 por exemplo, o enunciado exacerba o sofrimento da protagonista obesa que tem que passar fome para emagrecer, no romance Por que sou gorda, mamãe? O médico recomendou-lhe a redução de três garfadas por refeição, o mínimo de seis garfadas por dia. $\mathrm{O}$ alimento é farto e deve ser diminuído pela protagonista compulsiva, mas ele era parco e quase inexistente entre os internos esquálidos dos campos de concentração: nos campos, havia escassez de alimento; na narrativa, excesso. Por meio da comparação ("como num campo de concentração") constrói-se uma homologia que designa duas realidades cruzadas e antagônicas, o que institui o tom irônico. Este aplica-se a designação de coisas fora de lugar. A ambiguidade essencial da ironia está em aceitar, simultaneamente, sentidos cruzados que confundem o leitor, a quem cabe construir o atalho para chegar à ironia.

De forma semelhante, na citação: “O pai, feito o comandante de um campo de extermínio, assumiu o controle do carrinho (do aeroporto)," ${ }^{58}$ do conto "O homem que voltou ao frio", 59 revela-se uma entre várias que atravessam essa narrativa, e servem para marcar a estada de um finlandês indesejado em Porto Alegre e sua construção como vítima de um desencontro. Por meio do recurso à menção aos campos de concentração nazistas, o relato evoca a desgraça da presença desse jovem que chega intempestivamente a Curitiba para permanecer e se casar com a jovem que conhecera em sua estada em Israel. Desde sua chegada se dá a premonição de sua morte no final da narrativa. O finlandês, não judeu, não consegue fazer sua conversão ao judaísmo e quer se casar com a jovem judia de Porto Alegre, que ele conheceu um dia em um kibutz, e com ela ter filhos judeus. O pai da pretendida

\footnotetext{
${ }^{57}$ MOSCOVICH, Cíntia. Por que sou gorda, mamãe? Rio de Janeiro. São Paulo: Record. 2006. p. 231.

${ }^{58}$ MOSCOVICH, Cíntia. Anotações durante o incêndio. Porto Alegre: L\&PM, 2001. p. 36.

${ }^{59}$ MOSCOVICH, 2001.
} 


\section{Arquivo Maaravi}

trabalhará contra as intenções do rapaz, com a anuência da filha e da família. O "carrinho" do exemplo citado é o que contém a valise do estrangeiro recém-chegado, pilotado pelo pai, que lhe dará o rumo que ele deseja (um hotel) e não o jovem (a casa da amada).

Vejam-se, ainda, outras passagens: "Fomos juntos até o estacionamento, num silêncio constrangido - o silêncio de um forno crematório." 60 ; "O Ford Galaxie era um Auschwitz particular." $61 ;$ " [...] e me senti má porque fizera com que ele caísse numa emboscada: saía gás do chuveiro." ${ }^{2}$; "Sentia-me a maldita que havia encaminhado um homem a um campo de concentração." 63

Essas construções baseadas em litotes (uso do negativo pelo afirmativo; o grande pelo pequeno; o terrível pelo banal) são, afinal, um procedimento que evoca a Shoah como lugar de memória ou, ao contrário, como lugar de esquecimento? ${ }^{64} \mathrm{O}$ recurso à evocação institui uma gravidade (falsa) advinda do vínculo ao referente "Shoah", que, no entanto, tem sua história eclipsada. Assim, a dimensão da tragédia do ocorrido contra judeus, homossexuais, ciganos e outras minorias, durante a Segunda Guerra Mundial vira clichê, e o leitor fica a meio caminho entre a memória e o esquecimento, pois a lembrança não the diz mais respeito, não o implica.

Os indivíduos que compõem um grupo podem pôr de lado acontecimentos que se produziram durante sua própria existência; mas poderão esquecer um passado (das dimensões da Shoah) transcorrido antes deles? Por isso, quando dizemos que um povo "recorda", em realidade isso equivale a dizer que um passado foi ativamente transmitido às gerações contemporâneas por intermédio daquilo que Yossef Yerushalmi chama de " canais e receptáculos da memória65" e que Pierre Nora

\footnotetext{
${ }^{60} \mathrm{MOSCOVICH}, 2001$.

${ }^{61} \mathrm{MOSCOVICH}, 2001$, p. 36.

${ }^{62} \mathrm{MOSCOVICH}, 2001$, p. 37.

${ }^{63} \mathrm{MOSCOVICH}, 2001$, p. 43.

${ }^{64}$ Ver: GLANTZ, Margo. Animal de dos semblantes. In:
} Historia de uma mujer que caminó por la vida com zapatos de diseñador. Barcelona: Anagrama, 2005. p. 58- 93. Nesse conto, a autora também mescla os acontecimentos do dia a dia com catástrofes, perseguições. Enquanto narra uma história que apresenta uma profusão de cães que transitam, se movem e desaparecem, ela vai desvelando uma outra história protagonizada por judeus mortos na Shoah e por desaparecidos assassinados durante a ditadura militar argentina. Esses enredos subterrâneos confluem com outros de fatos usuais.

${ }^{65}$ Cf. YERUSHALMI, Yossef Hayim, Zakhor: Jewish History and Jewish Memory. Washington: University of Washington Press, 1982. Cf. ainda "Memória coletiva", no sentido que lhe atribui Halbwachs, isto é, uma corrente de pensamento contínuo, de uma comunidade que não tem nada de artificial, pois não retém do passado senão aquilo que 


\section{Arquivo Maaravi}

chama com acerto "os lugares de memória". ${ }^{66}$ Assim, um povo "esquece" quando a geração que recebe o passado não o transmite à seguinte, ou quando essa geração recusa o que recebeu ou cessa de transmiti-lo. A ruptura na transmissão pode produzir-se bruscamente ou pode abarcar várias gerações. As novas gerações podem também adaptar o legado da lembrança a situações inusuais, em que o leitor se pergunta, como no caso das citações mencionadas, se a catástrofe está sendo lembrada ou esquecida?

A Shoah, nos textos de Moscovich, aparece não só como figura de linguagem, mas também como tema. É o caso do relato traumático da vida de Dona Dora, ${ }^{67}$ sobrevivente dos campos de concentração, que mora trancafiada numa casa, com marido e filho, um menino surdo-mudo, esquelético e arredio. Viviam com as venezianas lacradas por paus e tijolos e um estoque de comidas em prateleiras enormes que cobriam todas as paredes, inclusive as janelas. Estas vedavam a visão do mundo presente que já era outro. Não mais a Europa, os campos de concentração, mas o Brasil, Porto Alegre, século XXI.

Aqui, o excesso, retoma a experiência do Holocausto como desmedida, isto é, por meio da construção de deslocamento e da hipérbole. $\mathrm{O}$ trauma do sofrimento e da privação vira uma espécie de contraexemplo, de encarte, num relato mais amplo em que o comedimento é o centro exemplar de onde se extrai o ensinamento transmitido pelo pai de família. É para enfatizar o comedimento como regra de vida, que se presta o excesso do relato da família que vive anacronicamente a Shoah em outro lugar e em outro tempo: "Não era mera frase de efeito, a gravidade com que papai a pronunciou estava no lugar devido e adequado. Havia uma medida nas coisas e devíamos aprendê-la." 68

Nesses exemplos, nota-se que a Shoah é um instrumento para a construção de metáforas, metonímias, comparações, hipérboles, litotes, com o propósito de tratar de outras situações que não o Holocausto propriamente dito. Pertencente à terceira geração pós-catástrofe, o movimento da escritora é ambíguo, porque desvencilha-se de uma história marcada pela destruição e pelo trauma vivenciados por ela como herança e, ao mesmo tempo, a utiliza na construção de figuras de linguagem, trampolins para a obtenção da graça, da ironia, motivadas pela desproporção entre o que foi o morticínio coletivo da Segunda Guerra Mundial e as situações mais ou

dele é ainda vivo ou capaz de viver na consciência do grupo que a mantém. Ver: HALBWACHS, M.. La mémoire collective. 2.éd. revue e augmentée. Paris: PUF, 1968. p. 70.

${ }^{66}$ NORA, Pierre et al. Entre memória e história: a problemática dos lugares. Projeto História. Revista do Programa de Estudos Pós-Graduados de História, v. 10, 1993.

${ }^{67}$ Episódio incluso no romance Por que sou gorda, mamãe?

${ }^{68} \mathrm{MOSCOVICH}, 2006$, p. 214-219. 


\section{Arquivo Maaravi}

Revista Digital de Estudos Judaicos da UFMG

ISSN: $1982-3053$

menos prosaicas da vida de uma família judaica, relativamente abastada e burguesa, na cidade de Porto Alegre.

\section{Michel Laub}

No romance Diário da queda, ${ }^{69}$ Michel Laub parte de um acontecimento nuclear, que dá sentido ao romance como um todo. Trata-se do episódio violento vivenciado pelo narrador junto a um grupo de meninos que marcará não só sua vida de adolescente, como também a de adulto - um passado de relações conturbadas, incluindo a própria história familiar. É o trabalho de rememoração que trará à tona os questionamentos do garoto que se dá conta, aos poucos, do ódio que ele e os colegas, matriculados numa escola judaica, dirigem ao único não-judeu da sala. ${ }^{70} \mathrm{O}$ desprezo coletivo por João (este é seu nome), enterrado e humilhado repetidas vezes no tanque de areia da escola, revela ao narrador o vazio do discurso de seu pai sobre antissemitismo.

É ousada a construção da trama, que em seu trânsito incessante entre delicados polos da natureza humana mostra como o excluído pode assumir o papel do opressor e, de modo geral, como os papéis são intercambiáveis. No percurso, o romance alude a múltiplas ressonâncias: à ausência de uma rede de proteção que lança os personagens a lugares inimagináveis; à exploração do "espaço biográfico" que dá voz à experiência; a diferentes formas de aniquilação; a abismos insondáveis de uma insuspeitada humanidade; à memória traumática transformada em objeto de indagação; ao esquecimento; à discussão relativa ao dever ético de lembrar. Enfim, a diversidade de registros traça uma cartografia intrincada que sinaliza os caminhos da queda e de seu reconhecimento.

Para tramar tantos fios, o romance reúne e entrecruza três diários e o relato se faz a partir do confronto de três gerações, representadas pelo avô, o pai e o filho narrador.

Escrito em primeira pessoa, não fica claro se se trata de autobiografia ou de uma autobiografia ficcional, pois o autor embaralha dados próprios também atribuídos ao narrador-protagonista, o que pode levar o leitor a pensar que se trata de uma autobiografia. $\mathrm{O}$ confronto geracional faz emergir um segmento temático voltado à memória individual e à memória coletiva. Como o avô é um egresso do campo de

${ }^{69}$ LAUB, Michel. Diário da queda. São Paulo: Companhia das Letras, 2011.

${ }^{70} \mathrm{O}$ romance se desenvolve a partir da "perturbação de identidade", isto é, ele abre espaço para algumas coincidências entre o narrador e a pessoa "real". Ver, a esse própósito, Régine Robin, Identidad, memória, relato. La imposible narración de sí mismo. Buenos Aires: Cuadernos de Posgrado, Facultad de Ciencias Sociales-CBC, UBA, 1996. Para a autora, "autoficción" seria "una ficción que alguien decide hacer de si mismo". Ao contrário do autobiógrafo, que conta sua vida para encontrar nela um sentido ou uma justificação, o "autoficcionário" é o artista que extrai de si emoções, sensações, imagens de pessoas e de espaços e as verbaliza. 


\section{Arquivo Maaravi}

concentração de Auschwitz, repete-se, à exaustão, o mote de que "nós" (talvez mais os judeus do que os não judeus) não podemos esquecer o assassinato em massa consumado pelo nazifascismo.

O avô escapa do campo, viaja para o Brasil, Porto Alegre, casa-se com uma não judia que se converte ao judaísmo e nunca, em tempo algum, se refere à sua experiência de prisioneiro e de sobrevivente. Acaba se suicidando e deixa 16 volumes de memórias escritos. $\mathrm{O}$ filho de 14 anos é quem abre a porta e encontra o pai morto por uma bala de revólver. Como o avô não se refere à sua vida em Auschwitz, o leitor espera que os volumes revelem o que nela se velou. Mas não. Eles tratam de como a vida deve ser e não de como é ou foi. Lembrando um pouco os verbetes de Bouvard e Pécouchet, de Gustave Flaubert que compõem um dicionário de ideias feitas de citações, os textos do avô são também elaborados a partir de lugares comuns, mas tratam de higiene, principalmente, fabricando um presente fictício, um ato mudo, em que o principal permanece calado, em detrimento de qualquer registro realista do que ocorreu. Aliás, toda informação que o narrador passa do avô é sempre por intermédio de terceiros. Também a limpeza, a assepsia, no texto do avô, reflete em negativo um passado lançado num ponto cego que ele não consegue digerir e revelar. Veja-se:

Esposa - pessoa que se encarrega das prendas domésticas, cuidando para que sejam empregados procedimentos os mais rigorosos de higiene na casa e também para que no dia do marido não existam perturbações quando ele desejar ficar sozinho. ${ }^{71}$

Observe-se, ainda, a história edulcorada do Brasil, contada a partir do ponto de vista do avô:

o Brasil de 1945 era um país que não tinha passado pela escravidão. Onde nenhum agente do governo fez restrições à vinda de imigrantes fugidos da guerra. Um lugar repleto de oportunidades... ${ }^{72}$

Se o avô não se refere a sua condição de imigrante e a sua vitimização pelo nazismo, o pai o faz por ele, determinando o que não pode ser esquecido: o que uma maioria é capaz de fazer com uma minoria, num esquema rígido de perpetrador e vítima. Ironicamente, ele sofrerá de Alzheimer e perderá a memória, diluída pela doença degenerativa.

\footnotetext{
${ }^{71}$ LAUB, 2011, p. 31.

${ }^{72}$ LAUB, 2011, p. 26.
} 


\section{Arquivo Maaravi}

O filho/narrador compõe seu livro em fragmentos numerados, o que lhe permite transitar entre histórias e tempos; assim, ele vai e volta de modo fluido entre blocos narrativos, que ora têm o avô, o pai ou a ele próprio e seus pares como figuras centrais. A experiência marcante de sua vida adolescente é a que vive na escola judaica, na qual se admitiu um aluno pobre, não judeu, filho de um cobrador de ônibus, que vai pôr em evidência um outro lado da moeda. Nessa comunidade, os judeus são maioria e João, o não judeu, é motivo de chacota dos colegas. Enterramno cada dia no tanque de areia, caçoam dele, até completar 13 anos, quando o pai resolve fazer uma festa para retribuir o convite aos colegas que sempre o incluíam nas festas de comemoração do ritual judaico de passagem para a idade adulta, que ocorre, para os meninos, aos 13 anos - o bar mitzvá. Festa pobre, comida pobre, os convidados da família também são gente pobre. Os colegas de João combinam, então, lançá-lo 13 vezes ao alto, como faziam com os demais, só que, no décimo terceiro lance, deixariam que ele caísse no chão. $O$ narrador se pergunta se ele participou dessa emboscada por causa dos outros colegas, se foi ativo na elaboração da ideia, se a culpa era dos outros, ou era dele:

Não sei se fiz aquilo apenas para me espelhar nos meus colegas, João sendo jogado para cima uma vez, duas vezes, eu segurando até que na décima terceira vez e com ele ainda subindo eu recolhi os braços e dei um passo para trás e vi João parado no ar e iniciando a queda, ou se foi o contrário: se no fundo, por essa ideia dos dias anteriores, algo que eu tivesse dito ou uma atitude que tivesse tomado, uma vez que fosse, diante de uma pessoa que fosse, independentemente das circunstâncias e das desculpas, se no fundo eles também estavam se espelhando em mim. ${ }^{73}$

E também em:

era só ter esticado o braço, só ter amortecido o impacto e João teria levantado, e eu nunca mais veria nele o desdobramento do que tinha feito por tanto tempo até acabar ali, a escola, o recreio, as escadas e o pátio e o muro onde João sentava para fazer o lanche, o sanduíche jogado longe e João enterrado e eu me deixando levar com os outros, repetindo os versos, a cadência, todos juntos e ao mesmo tempo, a música que você canta porque é só o que pode fazer aos treze anos: come areia, come areia, come areia, gói filho de uma puta. ${ }^{74}$

Mais do que as histórias de extermínio dos judeus na Segunda Guerra Mundial que o narrador conhece de forma abstrata, é a experiência de terem provocado a queda

${ }^{73}$ LAUB, 2011, p. 22.
${ }^{74}$ LAUB, 2011, p. 22. 


\section{Arquivo Maaravi}

de João, que se torna decisiva para ele. Agora, ele é parte do coletivo que agride o diferente e não sairá imune, mudando o seu ponto de vista em relação a si e aos colegas. Este momento marca a perda da inocência do narrador-protagonista, a sua queda. Daí para frente ele terá que se haver com quem é, o que fez, o que deve ou pode fazer, seus limites, enfim. Sua inadaptação passa a se manifestar a partir desse ato, em conflitos consigo próprio, com o pai que não o enxerga, nem o salva, com o mundo e suas regras; a partir desse dado, o inferno existencial e moral vai ganhando espaço.

A sensibilidade e a delicadeza no trato de temas complexos do cotidiano, a riqueza nas descrições sensoriais, nas digressões, atribuem ao texto uma dimensão rica e perturbadora, graças às revelações que vão ocorrendo pouco a pouco e se interligando em diferentes pontos. Desse modo, o narrador arremata:

Depois que fiquei amigo de João também comecei a olhar para os meus amigos sem entender por que eles tinham feito aquilo, e como eles tinham me cooptado, e comecei a ter vergonha de ter gritado gói filho de uma puta, e isso se misturava com o desconforto cada vez maior diante do meu pai, uma rejeição à performance dele ao falar de antissemitismo, porque eu não tinha nada em comum com aquelas pessoas além do fato de ter nascido judeu, e nada sabia daquelas pessoas além do fato de elas serem judias, e por mais que tanta gente tivesse morrido em campos de concentração não fazia sentido que eu tivesse de lembrar disso todos os dias. ${ }^{75}$

Como o avô egresso de Auschwitz não se refere ao passado, o narrador remete sempre a É isto um homem?, ${ }^{76}$ de Primo Levi. A problematização relativa ao gesto político de toda escrita comparece nas referências textuais desse autor. Levi defendia a necessidade de testemunhar, para evitar que as atrocidades do nazismo e a redução do homem a coisa fossem esquecidos. Para o escritor, é um imperativo de ordem ética articular um discurso que recupere essa passagem da vida dos sobreviventes, por mais doloroso que seja o ato de narrar. Esse suposto dever é rechaçado pelo avô no romance, que insiste em fugir do passado, anulando essa experiência, e, no limite, anulando-se no ato do suicídio. Tanto Levi quanto o avô se suicidam e as motivações podem ser as mesmas ou não. Mas o certo é que ambos manifestam a dificuldade de continuar vivos.

\footnotetext{
${ }^{75}$ LAUB, 2011, p. 37.

${ }^{76}$ LEVI, 1988.
} 


\section{Arquivo Maaravi}

Por outro lado, enquanto João cai e se machuca, é hospitalizado e custa a voltar a caminhar, o narrador não consegue encarar a si próprio e vai buscar algum alívio na bebida, vício iniciado já na adolescência, que durará até que se confirme a doença do pai e a vida do narrador passe para outra etapa, tendo como horizonte o nascimento de um filho.

Como efeito de sua queda, o narrador vai para uma escola pública e aproxima-se de João. Os dois estão na mesma classe. Agora é este, fortalecido, que denuncia o amigo aos novos colegas e conta como ele foi desleal e partícipe na provocação do acidente.

A partir de ações que retornam, o escritor constrói uma reflexão corajosa sobre identidades, afetos e perdas, destacando não só o silêncio do avô em relação à própria experiência em Auschwitz, como também em relação à experiência da paternidade:

uma única palavra das que costumamos ver nas memórias de sobreviventes de campos de concentração, a vida que segue depois que se sai de um campo como Auschwitz, a alegria que se consegue ter novamente ao ver um filho crescer como resposta a tudo o que se viu em Auschwitz... ${ }^{77}$

Numa prosa que oscila entre violência, lirismo e ironia, com pausas para uma neutralidade quase documental na descrição de cheiros, gostos, sons, fatos e sentimentos, o romance delineia uma viagem inusitada de um homem que precisa fazer uma escolha decisiva para nortear sua vida. ${ }^{78}$

Como o romance de Laub toca em questões voltadas ao testemunho e ao Holocausto, trago para discussão o livro Homo sacer ${ }^{79}$ em que Giorgio Agamben aponta para as profundas transformações ocorridas na cena política contemporânea com a instituição do que chama de biopolítica - o homem visado como corpo - e o surgimento do campo de concentração como paradigma do poder.

O escritor se detém na Segunda Guerra Mundial e oferece ao leitor em sua abordagem dos campos e do Holocausto uma compreensão abstrata do fato, aludindo menos a seus componentes históricos que a seu núcleo estrutural, de modo a poder estender, a partir de Auschwitz, sua interpretação de outros eventos de opressão no século XX.

${ }_{77}$ LAUB, 2011, p. 47.

${ }^{78} \mathrm{O}$ romance coloca em foco a terceira geração pós-Shoah e dá relevo a aspectos distintos de como essa herança marca o protagonista.

${ }^{79}$ AGAMBEN, Giorgio. Homo sacer: o poder soberano e a vida nua I Trad. Henrique Burigo. Belo Horizonte: Editora UFMG, 2002. 


\section{Arquivo Maaravi}

O mesmo parece ocorrer com Diário da queda, de Laub. Embora o nazismo se apresente por intermédio da biografia do avô e Auschwitz seja mencionado, esse dado repercute em outros momentos do romance que lidam com o sofrimento da aniquilação física provocado pelo mal humano, que o homem alberga dentro de si, exigindo a vigilância do bem, ou que se repare o mal de certa forma. Laub, em notas, insere também informações que corrigem a história do extermínio de judeus, obtidas por meio de pesquisa na internet; os 52 fornos crematórios existentes em Auschwitz não teriam a capacidade de queimar 4.756 cadáveres por dia, média necessária para se chegar ao número total de mortos das estatísticas oficiais. Aliás, esse tipo de argumento é utilizado pelos revisionistas para provar que não houve Holocausto, que é tudo invenção dos judeus. Verdade ou mentira? Isso não faria diferença para seu pai, para quem Auschwitz era, acima de tudo, um conceito em que se acredita ou não. O filho, no entanto, na ficção, reluta em acreditar:

Quando criança eu sonhava com essas histórias, as suásticas ou as tochas dos cossacos do lado de fora da janela, como se qualquer pessoa na rua estivesse pronta para me vestir um pijama com uma estrela e me enfiar num trem que ia rumo às chaminés, mas com os anos isso foi mudando. Eu percebi que as histórias se repetiam, meu pai as contava da mesma forma, com a mesma entonação, e até hoje sou capaz de citar exemplos que volta e meia deixavam a voz dele embargada, a prisão da garotinha, a separação dos dois irmãos, o médico e o professor e o carteiro e a mulher grávida que atravessou a Polônia antes de ser pega numa emboscada no mato. Alguma coisa muda quando você vê o seu pai repetindo a mesma coisa uma, duas ou quinhentas vezes, e de repente você não consegue mais acompanhá-lo, se sentir tão afetado por algo que aos poucos, à medida que você fica mais velho, aos treze anos, em Porto Alegre, morando numa casa com piscina e tendo sido capaz de deixar um colega cair de costas no aniversário, aos poucos você percebe que isso tudo tem muito pouca relação com a sua vida. ${ }^{80}$

Se a culpa recai sobre o sistema, o estado totalitário como um todo, a quem compete julgar? Basicamente a ninguém, responde Primo Levi, ${ }^{81}$ para quem não é possível "reduzir a rede das relações humanas dos Lager a apenas dois blocos, o das vítimas e o dos opressores". A tendência maniqueísta à simplificação tende a propor a divisão da humanidade em dois grupos claramente distintos: o dos bons e o dos maus. A lição do campo, ao contrário, era que "o inimigo estava ao redor, mas também dentro, o 'nós' perdia seus limites e os contendores não eram dois, não se distinguia

\footnotetext{
${ }^{80}$ LAUB, 2011, p. 36.

${ }^{81}$ LEVI, 1990, p.17.
} 


\section{Arquivo Maaravi}

uma fronteira, mas muitas e confusas, talvez inúmeras, separando cada um do outro" .82

Definir o humano a partir de uma essência é, de certa maneira, repetir a lógica SS e sua repartição soberana entre humanidade alemã e inumanidade judaica, entre moral humana alemã, e venalidade sub-humana judaica, entre o patrimônio genético do povo alemão e a "vida nua" dos "piolhos" judeus, exterminados nas câmaras de gás. O novo imperativo talvez seja não apenas lembrar ou esquecer, mas mapear uma nova ética que impeça o circuito da repetição. Essa proposta subjaz no livro de Laub. Ele recoloca todas essas questões abstratas vivenciadas em âmbito familiar, trata da lembrança e do esquecimento, de diferentes níveis de queda, mas desmascara as diferenças rígidas entre bons e maus, nós e eles, mostrando como as personagens deslizam em seus papéis, fazem escolhas, sofrem, praticam crueldades, têm sentimentos contraditórios e sobrepostos; nesse entretempo, as identidades se erigem e se desmontam ${ }^{83}$. A narrativa de Laub é um romance de formação e dentro dessa moldura enlaçam-se três gerações. Se o diário do avô apresenta o que a vida deveria ser, o do pai o "corrige", pois trata das coisas que importam, voltadas simbolicamente ao filho, que tem que lidar com esse legado frente a uma existência em curso:

As memórias de meu avô podem ser resumidas na frase como o mundo deveria ser, e daria para dizer que as do meu pai são algo do tipo como as coisas foram de fato, e se ambos são como que textos complementares que partem do mesmo tema, a inviabilidade da experiência humana em todos os tempos e lugares, o meu avô imobilizado por isso, o meu pai conseguindo ir adiante apesar disso, e se é impossível falar sobre os dois sem ter de também firmar uma posição a respeito, o fato é que desde o início escrevo este texto como justificativa para essa posição. ${ }^{84}$

\footnotetext{
82 LEVI, 1990, p.22.

${ }^{83}$ Remeto o leitor a: KEILSON, Hans Comédia em tom menor. Trad. Luiz A. de Araújo. São Paulo: Companhia das Letras, 2011, publicado originalmente em 1947. Nele, o autor apresenta a história de um refugiado judeu na Holanda, após a ocupação dos Países Baixos, escondido por um casal de não judeus. O judeu morre depois de um ano e o casal deixa um rastro que permitirá identificá-los como traidores do sistema, pois tinham auxiliado um judeu. Essa circunstância os obriga a se esconderem e viverem refugiados, postos ironicamente na mesma posição que os judeus. Essas mudanças de lugar interessam para romper oposições esquemáticas que, muitas vezes, prejudicam a reflexão sobre o ocorrido durante a Segunda Guerra Mundial.

${ }^{84}$ LAUB, 2011, p. 46.
} 


\section{Arquivo Maaravi}

Ao dar relevo à câmara escura das lembranças e das observações que desenham uma espécie de topografia familiar em que o próximo e o remoto se mesclam, a opção do narrador pela vida marca o fim do relato. Mas no trajeto ele questiona as relações familiares, o funcionamento de sua comunidade, acentuando a dúvida em relação a um passado cultural e religioso fundado na manutenção de um sistema dogmático. O instante congelado, o retrato imóvel, imagens comumente usadas para descrever a memória bem como a escrita memorialística, revelam-se insuficientes quando tratados como algo estático, pedaços soltos do tempo, que só ganham sentido em meio à multiplicidade vertiginosa de estímulos que constitui a vida. Em Diário da queda, Laub enfrenta esse material com maturidade e rigor, revelando-se um autor cuja obra propicia novas indagações acerca da tradição e da natureza humana.

Recebido em: 20/09/2019.

Aprovado em: 20/10/2019. 